Abstract

\title{
Turbulent diffusion mass transfer in fluidised beds
}

\author{
by F. Couret*, F. Vergnes** and P. Le Goff***
}

The general principles of fluidisation are reviewed, followed by a description of the principles of electrochemical mass transfer measurement, local porosity measurement by electrical conductivity, and measurement of porosity fluctuations.

An original experimental layout is briefly described in which these three quantities are measured locally in a fluid bed with an aqueous alkaline potassium ferro--and ferri-cyanide solution.

The results of these measurements are given in the form of mass transfer vs. fluid flow velocity curves. Curves for vertical probe measurements show a maximum and some curves obtained with a horizontal probe also feature a minimum at high velocities. An explanation is given for this.

Except near the ends of the bed, porosity and porosity fluctuations do not vary with probe position along the bed centreline.

If the mass transfer data are plotted against porosity it is seen that maximum transfer is associated with a porosity value of 0.6 , and if the difference between the coefficients measured in the bed and in the liquid alone at the same interstitial velocity are plotted against porosity, the data for various particle sizes can be combined into a single curve. The downward limb of curves obtained with the probe vertical can be put in the general form $j_{\mathrm{I}} \varepsilon=1.21$ (Re')-0.52 for $6<R e^{\prime}<200$ and agrees well with the Jagannadha Raju correlation. The mass transfer data for the liquid alone also agree satisfactorily with published data.

Solid concentration fluctuations increase steadily with fluid velocity, and therefore also with porosity. With a similar theory to the van der. Waals gas density fluctuation theory it can be shown that the bed particles do not behave as independent entities but that they agglomerate and form groups, and that the smaller the particles, the bigger the groups are.

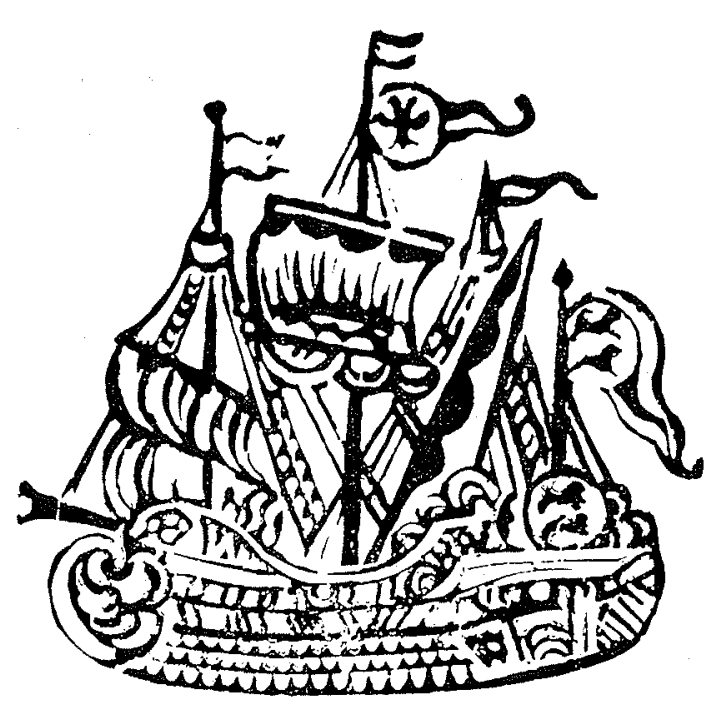

* Ingénieur de Recherches.

** Maître assistant de Génie chimique à l'ENSIG-Nancy.

*** Professeur de Génie chimique à l'ENSIC-Nancy et Directeur du Centre de Cinétique physique et chimique du C.N.R.S. 
rappelle

ses volumes

hors-série

et ses

numéros

spéciaux

\section{HYDRAULIQUE ET ELECTRICITE FRANÇAISES}

Edition anglaise : Un volume (1950), 413 pages............... Broché

\section{B O R T}

Un volume (1953), 367 pages

Broché

$50 \mathrm{~F}$

\section{DONZERE-MONDRAGON}

Un volume $(1955), 486$ pages........................ Relié

\section{TIG N E S}

Un volume $(1958), 440$ pages $\ldots \ldots \ldots \ldots \ldots \ldots \ldots \ldots \ldots$ Relié

\section{LE DANUBE}

№ 2/1964 de "La Houille Blanche ", 218 pages.............. Broché $50 \mathrm{~F}$

\section{LES ENERGIES DE LA MER}

IV Journées de l'Hydraulique de la Société Hydrotechnique de France (1956).

Deux volumes, 751 pages......................... Brochés

\section{TURBINES ET POMPES HYDRAULIQUES}

$V^{\text {es }}$ Journées de l'Hydraulique de la Société Hydrotechnique de France (1958).

Deux volumes, 730 pages........................... Brochés

\section{LHYDRAULIQUE SOUTERRAINE}

Vles Journées de l'Hydraulique de la Société Hydrotechnique de France (1960).

Deux volumes, 663 pages........................... Brochés

\section{BULLES ET GOUTTES}

La tension superficielle en hydraulique

VII es Journées de l'Hydraulique de la Société Hydrotechnique de France (1962).

Deux volumes, 624 pages............................ Brochés

\section{LES INSTABILITES EN HYDRAULIQUE} ET EN MECANIQUE DES FLUIDES

VIII $^{\text {es }}$ Journées de l'Hydraulique de la Société Hydrotechnique de France (1964). Deux volumes, 674 pages......................... Brochés

\section{L'HYDRAULIQUE DU POINT DE VUE MEDICAL}

$N^{\circ}$ 2/1966 de "La Houille Blanche ", 150 pages . .

\section{MACHINES HYDRAULIQUES}

$\mathbf{N}^{0}$ 2-3/1968 de «La Houille Blanche ", 150 pages. 